$\xi=-1$

\title{
Coconut Fiber Strengthen High Performance Concrete: Young's Modulus, Ultrasonic Pulse Velocity and Ductility Properties
}

\author{
M. A. Othuman Mydin *, N. Mohd Zamzani \\ School of Housing, Building and Planning, Universiti Sains Malaysia, 11800, Penang, Malaysia \\ *Corresponding author E-mail: azree@usm.my
}

\begin{abstract}
This paper emphasis on experimental investigation to govern the engineering properties such as young's modulus, pundit ultrasonic pulse velocity (UPV) and ductility of High Performance Concrete (HPC) with grade M60 with addition of coconut fibre (CNF) together with silica fume (SF) and pulverised fuel ash (PFA). For this study, 3 mixes were prepared. First was the CNFRC without any additives, secondly the CNFRC made by $10 \%$ replacement of cement weight with PFA and thirdly composition of $10 \%$ of cement weight was exchanged with SF. It should be pointed out that for each mix; CNF was included in the mixture ( $0.5 \%$ of the mix volume). The investigational results had shown that the Young's modulus of CNFRC, CNFR SFC and CNFR PFAC enhanced by about 6\%, 3\%, and $12 \%$ correspondingly. In terms of ductility, when control HPC specimens were subjected to axial compressive strength, slight preliminary cracks shaped on the surface of specimens. Among all HPC specimens tested, CNFR PFAC attained the utmost UPV at 28 day.
\end{abstract}

Keywords: Cellular mortar; Coconut fiber; Compressive strength; Flexural strength; Lightweight concrete; Tensile strength

\section{Introduction}

These days, the construction industry has been enthusiastically considering for novelty in the concrete which has high strength as well as durability, for the construction of high rise buildings, bridges and restoration of old structures $[1,2,3,4]$. High rise structures are typically solidly reinforced and have very little room for concrete element to be filled in which can be a major flaw if not filled and compressed entirely [5,6,7]. High Performance Concrete (HPC) is self-compacting and easily fills up the spaces between the reinforcing bars $[8,9,10]$.

High Performance Concrete (HPC) became commercially obtainable in Malaysia in the year 2004 [11,12]. The existence of HPC had led to the use of HPC in numerous bridge applications, comprising precast, pre-stressed girders; precast waffle slab for bridge decks and as a joint material between precast concrete deck panels and girders and between the flanges of neighboring girders $[13,14,15]$.

The coconut fibre (Figure 1) is commercial available in three forms, namely bristle (long fibres), mattress and decorticated [16]. These different types of fibres have different uses depending upon the requirement. In engineering, brown fibres are mostly used $[17,18]$. There are many general advantages of coconut fibres e.g. they are moth-proof, resistant to fungi and rot, provide excellent insulation against temperature and sound, not easily combustible, flame-retardant, unaffected by moisture and dampness, tough and durable, resilient, springs back to shape even after constant use, totally static free and easy to clean $[19,20,21]$. Coconut fibre also has been used to enhance concrete and mortar, and has proven to improve the brittleness, ductility and toughness of the concrete and mortar $[22,23,24]$.

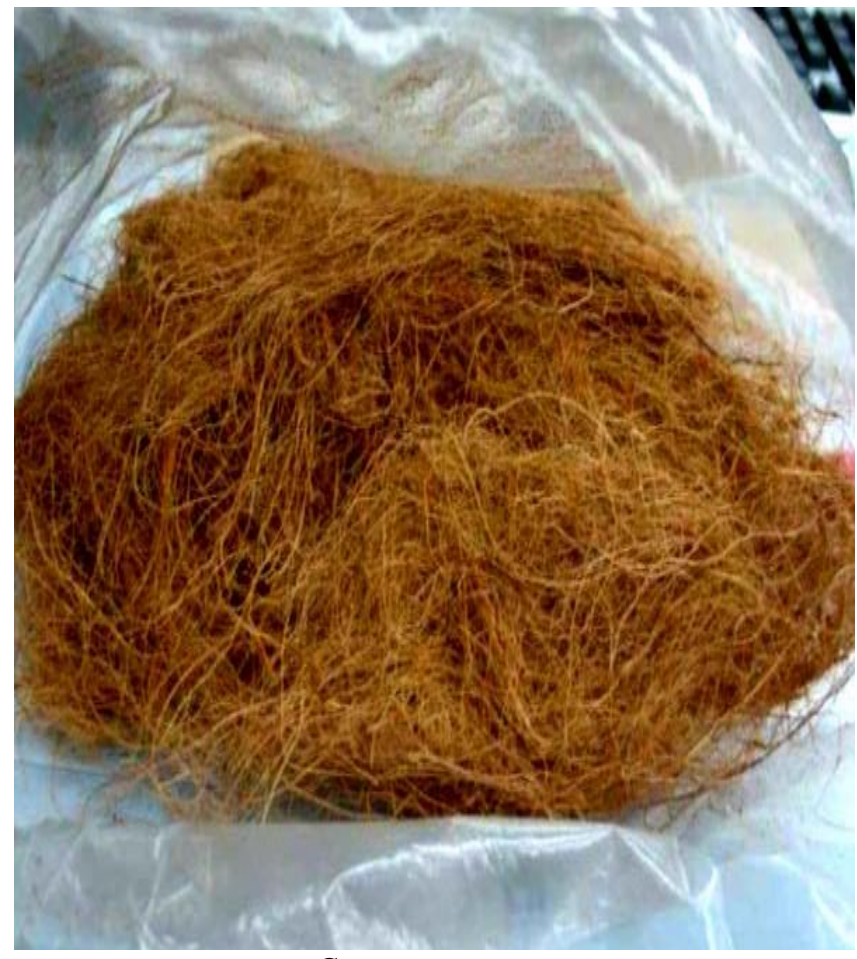

Fig. 1: Coconut nucifera fibre [16]

Therefore this this research aims to investigate the engineering properties of of High Performance Concrete (HPC) of grade M60 with addition of treated coconut fibre (CNF) together with silica fume (SF) and pulverised fuel ash (PFA) such as young's modulus, ultrasonic pulse velocity (UPV) and ductility. 


\section{Materials}

The Type I Portland cement was used in this study. The sand added into the mix has the modulus of 3.07 and specific gravity of 2.59. The maximum size of sand utilized was $5 \mathrm{~mm}$ which passing the $10 \mathrm{~mm}$ sieves analysis. On the other hand, silica fume implemented in the mix design has a specific surface of $0.236 \mathrm{~m}^{2} / \mathrm{g}$ and specific gravity of 2.25. In addition, the pulverised fuel ash utilized has a specific gravity of 2.12. Figure 2 shows the samples prepared for this study.

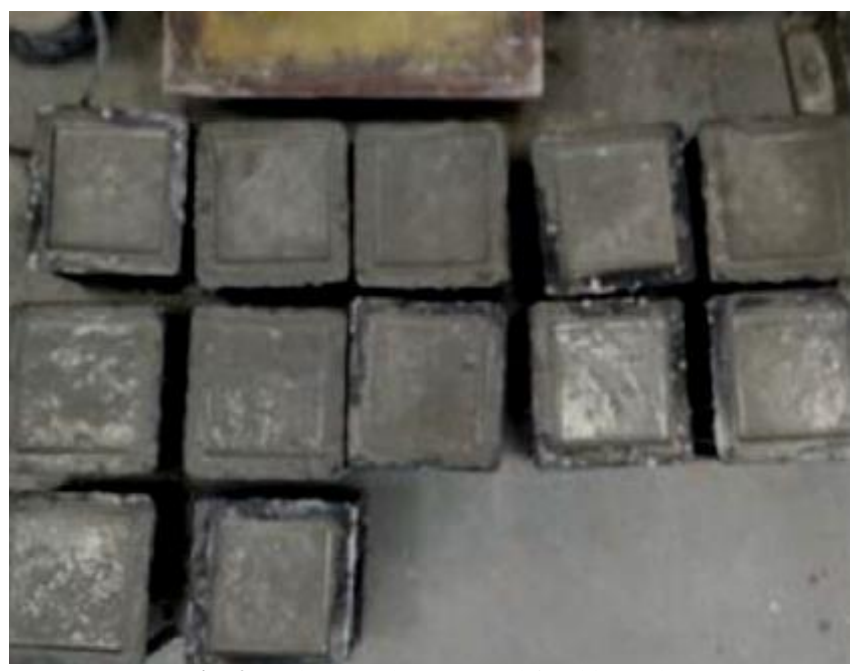

Fig. 2: Cube samples prepared for this study

Foam generator TM1 supplied by DRN resources was used as a foam generator machine in this study as shown in Figure 3.

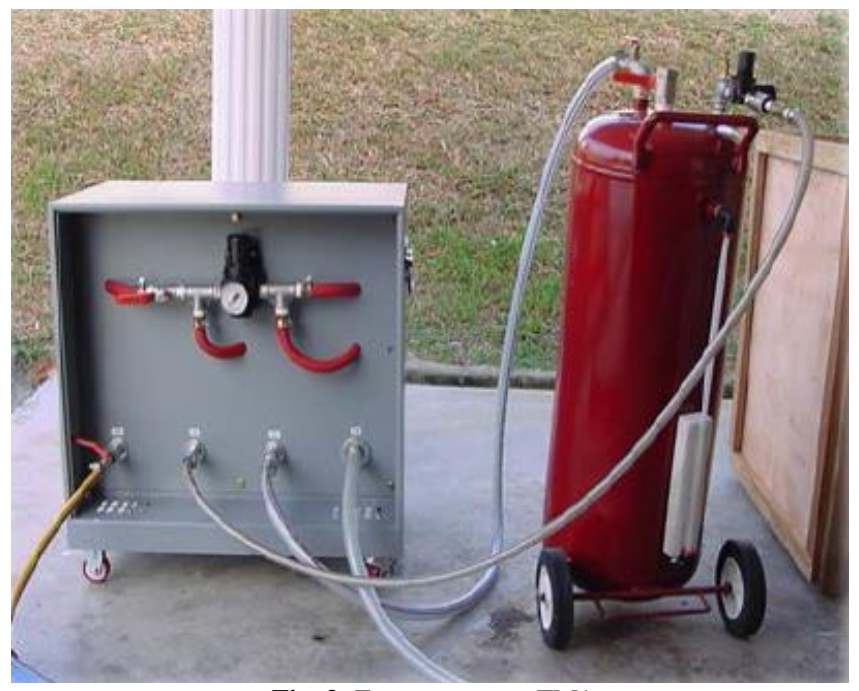

Fig. 3: Foam generator TM1

\section{Experimental}

\subsection{Young's Modulus and Ductility}

To monitor the Young's modulus, ductility and mode of failure, the axial compressive strength test was performed of a cube with a $100 \mathrm{~mm} \times 100 \mathrm{~mm} \times 100 \mathrm{~mm}$ dimension (Figure 4). The tests have been conducted as specified in the test method MS EN 12390-3: 2012 [25] with the aid of GOTECH GT-7001-BS300 Universal Testing Machine [26]. For each mixture, there were 9 samples were prepared and the tested at 7-day and 28-day.

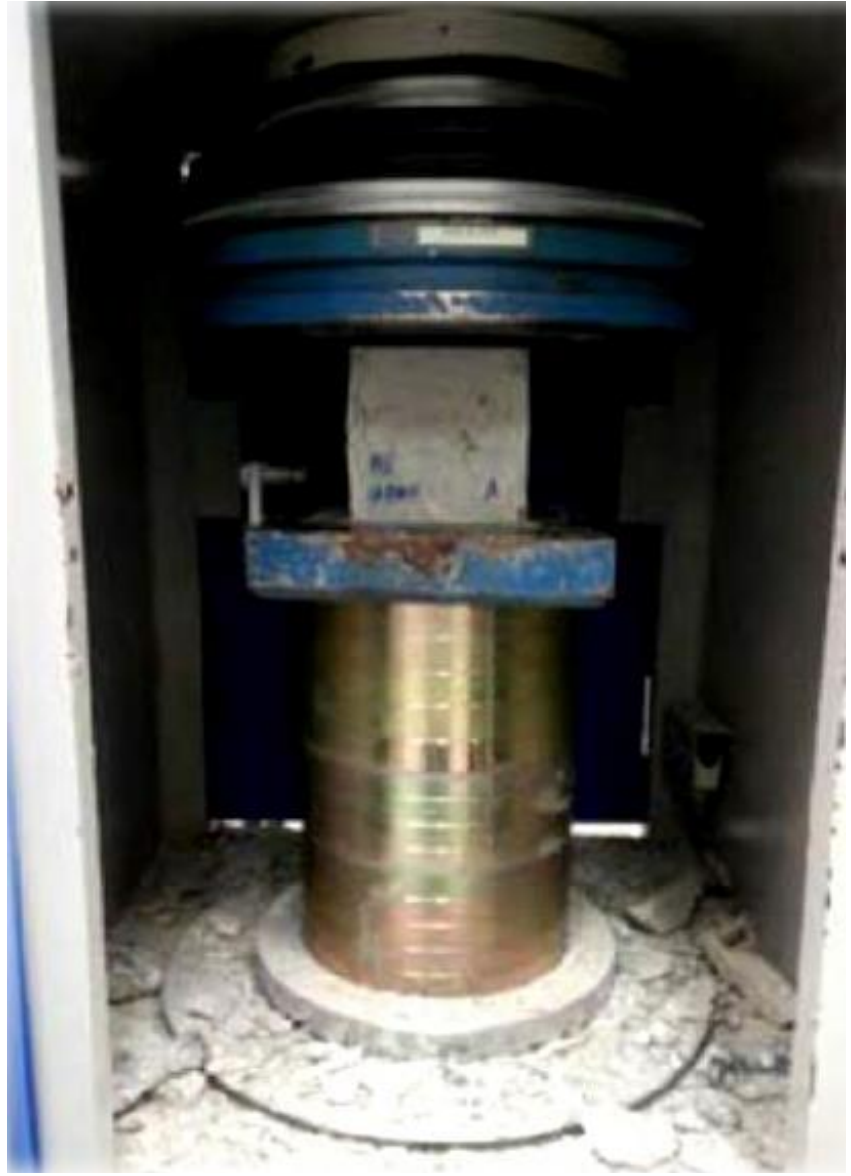

Fig. 4: Compression test on HPC cube

\subsection{Ultrasonic Pulse Velocity (UPV)}

The pundit UPV test was executed to govern the eminence of the HPC and occurrence of major and minor cracks in HPC. Ultrasonic Pulse Velocity was retrieved by Portable Ultrasonic Nondestructive Digital Indicating Test [27]. The test was performed conferring to the technique in BS EN 12504-4:2004. A prism sample with dimension $100 \mathrm{~mm} \times 100 \mathrm{~mm} \times 500 \mathrm{~mm}$ was prepared for this test (Figure 5).

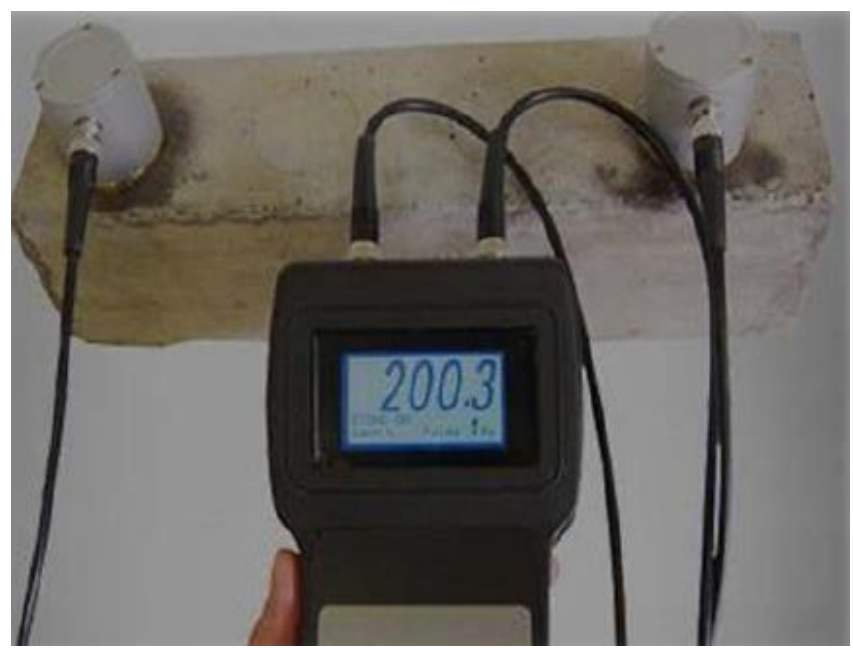

Fig. 5: Ultrasonic Pulse Velocity (UPV) Test on HPC prism

\section{Results and Discussion}

\subsection{Dry Density of HPC}

Density of HPC was measured at 7, 14 and 28 day which is achieved by weighting cubes before the compression test. For all 
mixes it was detected that, density of HPC was marginally enlarged over the age of testing [28]. Densities of the 4 admixtures are in the range of $2380-2595 \mathrm{~kg} / \mathrm{m}^{3}$ which are above the considered range for conventional normal strength concrete. It is important to attain a determined potential density because a high density stops the water vapour inside the HPC from absconding out of the concrete weight. On the other hand, there was an insignificant drop in the density of CNFR PFAC and CNFR SFC compared to CNFRC because PFA and SF have a lesser specific gravity compared to the cement. Specific gravity of PFA and SF are 2.21 and 2.18 correspondingly, which are rather lighter than Portland cement with a specific gravity of 3.14. Consequently, adding this pozzolans to a HPC mixture will not densify the material itself [29]. Influence of coconut fiber also reduced the HPC density by about $1.5 \%$ since attendance of voids in HPC decreases the density and strength as well.

\subsection{Young's Modulus}

Table 1 shows the results of dynamic Young's modulus of HPC at 28 day. Comparing to the control mix, the dynamic Young's modulus of CHFRC, CHFR SFC and CFHR PFAC improved by about $6 \%, 3 \%$, and $12 \%$ respectively. Among the factors affecting Young's modulus, moisture condition plays an important role comprehensively. Moist curing of the sample until testing time abridged drying and augmented Young's modulus of HPC as drying creates extra micro cracks in the transition region [8], which affects the stress-strain behaviour of the HBP specimens. It should be pointed out that coconut fiber also plays an important role to reduce the micro cracks in the transition zone [30].

Table 1: Dynamic Young's Modulus results of HPC

\begin{tabular}{|c|c|}
\hline HPC Mix & $\begin{array}{c}\text { 28-Day dynamic modulus of elasticity } \\
(\mathrm{Gpa})\end{array}$ \\
\hline Control & 44.74 \\
\hline CNFRC & 47.42 \\
\hline CNFR SFC & 46.08 \\
\hline CNFR PFAC & 50.11 \\
\hline
\end{tabular}

\subsection{Ultrasonic pulse velocity (UPV)}

Table 2 shows the Ultrasonic pulse velocity (UPV) results of HPC. Among all specimens, CNFR PFAC obtained the highest ultrasonic pulse velocity at 28 day. It was higher than UPV of the CNFR PFAC attained the utmost UPV at 28 day. It was higher than UPV of the CNFRC about $2 \%$ and the lowest UPV was achieved by CNFR SFC that was lower than that of CNFR SFC about $2 \%$. This has indicated that the pulverised fuel ash series specimens might have more compressed microstructures than silica fume series samples. It should be pointed out that HPC with less permeability has better strength and higher UPV since the presence of void on the path will upsurge the path length as it goes around the void. Ultrasonic pulse velocity of CNFRC, CNFR SFC and CNFR PFAC were between 4.2 and $4.5 \mathrm{~km} / \mathrm{s}$. Consequently, conferring to IS: 13311 Part 1, they were categorized as sound concrete with appropriate quality comprehensively.

Table 2: Ultrasonic pulse velocity results of HPC

\begin{tabular}{|c|c|}
\hline HPC Mix & $\begin{array}{c}\text { 28-Day dynamic modulus of elasticity } \\
(\mathrm{Gpa})\end{array}$ \\
\hline Control & 44.1 \\
\hline CNFRC & 45.8 \\
\hline CNFR SFC & 44.9 \\
\hline CNFR PFAC & 46.2 \\
\hline
\end{tabular}

\subsection{Ductility of HPC}

During the compression test, the crack pattern occurs was observed precisely. When the control specimen of HPC was exposed to axial compression, it can be seen that some minor initial cracks were shaped at the surface of the tested sample. The failure of the
HPC sample took place as soon as the decisive axial compressive load was accomplished. Conversely, when the CNFRC samples were loaded, it can be seen that it's still unbroken although the decisive axial compressive loading was applied on the sample.

\section{Conclusion}

After conducting extensive experimental research work, following conclusions can be drawn from the results:

- For all mixes it was detected that, density of HPC was marginally enlarged over the age of testing. Densities of the 4 admixtures are in the range of $2380-2595 \mathrm{~kg} / \mathrm{m}^{3}$ which are above the considered range for conventional normal strength concrete. It is important to attain a determined potential density because a high density stops the water vapour inside the HPC from absconding out of the concrete weight. On the other hand, there was a insignificant drop in the density of CNFR PFAC and CNFR SFC compared to CNFRC because PFA and SF have a lesser specific gravity compared to the cement

- Comparing to the control mix, the dynamic Young's modulus of CHFRC, CHFR SFC and CFHR PFAC improved by about $6 \%, 3 \%$, and $12 \%$ respectively.

- CNFR PFAC obtained the highest ultrasonic pulse velocity at 28 day. It was higher than UPV of the CNFR PFAC attained the utmost UPV at 28 day. It was higher than UPV of the CNFRC about $2 \%$ and the lowest UPV was achieved by CNFR SFC that was lower than that of CNFR SFC about $2 \%$.

\section{Acknowledgement}

The authors are grateful for the financial assistance of this research granted by Ministry of Higher Education Malaysia under FRGS Grant (Ref. No. 203/PPBGN/6711514)

\section{References}

[1] Strokova, VV, Cherevatova AV. 2013. Prospects of Application of Zero-Cement Binders of a Nonhydration Hardening Type, World Applied Sciences Journal 25 (1): 119-123

[2] Newman JB. 1993. Structural Lightweight Aggregate Concrete, Chapter 2: Properties of Structural Lightweight Aggregate Concrete. Chapman \& Hall.

[3] Herki BA, Khatib JM, Negim EM, 2013. Lightweight Concrete Made from Waste Polystyrene and Fly Ash. World Applied Sciences Journal, 21 (9): 1356-1360

[4] Ganesan S, Othuman Mydin MA, Md. Sani N, Che Ani AI. 2014. Performance of Polymer Modified Mortar with Different Dosage of Polymeric Modifier, MATEC Web of Conferences. 15: 01019.

[5] Othuman Mydin MA, Wang YC. 2012. Mechanical Properties of Foamed Concrete Exposed to High Temperatures. Journal of Construction and Building Materials. 26(1): 638-654.

[6] Roslan AH, Awang H, Othuman Mydin MA. 2013. Effects of Various Additives on Drying Shrinkage, Compressive and Flexural Strength of Lightweight Foamed Concrete ( LFC). Advanced Materials Research Journal. 626: 594-604.

[7] Othuman Mydin MA. 2013. Modeling of Transient Heat Transfer in Foamed Concrete Slab. Journal of Engineering Science and Technology. 8(3): 331-349.

[8] Balshin MY. 1949. Dependence of mechanical properties of metal powders on porosity and limiting properties of metal-ceramic materials, Dokl. Akad. Nauk. UzSSR, 67, No. 5, 831-834.

[9] Othuman Mydin MA, Sahidun NS, Mohd Yusof MY, Md Noordin N. 2015. Compressive, Flexural And Splitting Tensile Strengths Of Lightweight Foamed Concrete With Inclusion Of Steel Fibre. Jurnal Teknologi. 7(5): 45-50.

[10] Benayoune, A. A. Abdul Samad, D. N. Trikha, A. A. Abang Ali, S. H. M. Ellinna. 2008. Flexural Behavior of Pre-cast Concrete Sandwich Composite Panel-Experimental and Theoretical Investigations. Construction and Building Materials. 22: 580-592.

[11] Othuman Mydin MA, Mohamed Shajahan MF, Ganesan S, Md. Sani N. 2014. Laboratory Investigation on Compressive Strength and Micro-structural Features of Foamed Concrete with Addi- 
tion of Wood Ash and Silica Fume as a Cement Replacement, MATEC Web of Conferences. 16: 01004.

[12] Aldridge D, Ansell T. 2001. Foamed Concrete: Production and Equipment Design, Properties, Applications and Potential. In: Proceedings of one day seminar on foamed concrete: Properties, applications and latest technological developments, Loughborough University

[13] Khatib JM., Shariff S, Negim EM. 2012. Effect of Incorporating Foamed Glass on the Flexural Behaviour of Reinforced Concrete Beams, World Applied Sciences Journal 19 (1): 47-51

[14] Norgaard J, Othuman Mydin MA. 2013. Drywall Thermal Properties Exposed to High Temperatures and Fire Condition. Jurnal Teknologi, 62 (1): 63-68

[15] Demirbog R, Gul R. 2003. The Effects of Expanded Perlite Aggregate, Silica Fume and Fly Ash on the Thermal Conductivity of Lightweight Concrete. Cement and Concrete Research Journal. 33(5): 723-727

[16] Othuman Mydin MA, Wang YC. 2012. Thermal and Mechanical Properties of Lightweight Foamed Concrete (LFC) at Elevated Temperatures. Magazine of Concrete Research. 64(3): 213-224.

[17] Kearsley EP, Wainwright PJ. 2002. The effect of porosity on the strength of foamed concrete. Journal of Cement and Concrete Research 32, No. 2, 233-239.

[18] Khennane A, Baker G. 1993. Uniaxial model for concrete under variable temperature and stress, Journal of Engineering. Mechanics (ASCE) 119, No. 8, 1507-1525.

[19] Shanmugam, N. E., Lakshmi. B. 2001. State of the Art Report on Steel-concrete Composite Columns. Journal of Constructional Steel Research. 57(1):1041-1080

[20] Okpala DC. 1990. Palm Kernel Shell as Lightweight Aggregate in Concrete. Building and Environment Journal. 25(4): 291-296.

[21] Soleimanzadeh S, Othuman Mydin MA. 2013. Influence of High Temperatures on Flexural Strength of Foamed Concrete Containing Fly Ash and Polypropylene Fiber. International Journal of Engineering. 26(1): 365-374.

[22] Hoff GC. 1972. Porosity-strength considerations for cellular concrete. Journal of Cement and Concrete Research 2, No. 1, 91-100.

[23] Othuman Mydin MA. 2013. An Experimental Investigation on Thermal Conductivity of Lightweight Foamed concrete for Thermal Insulation. Jurnal Teknologi. 63(1): 43-49.

[24] Bush, T. D., and G. L. Stine. 1994. Flexural Behavior of Composite Prestressed Sandwich Panels. PCI Journal. 39(2): 112-121.

[25] Salmon, D. C., A. Einea, M. K. Tadros, and T. D. Culp. 1997. Full Scale Testing of Precast Concrete Sandwich Panels. ACI Structural Journal. 94(4): 354-362.

[26] Sahu JN, Abnisa F, Daud WMA Husin WMW. 2011. Utilization Possibilities of Palm Shell as a Source of Biomass Energy in Malaysia by Producing Bio-oil in Pyrolysis Process. Biomass and Bioenergy. 35(5): 1863-1872.

[27] Othuman Mydin MA. 2011. Thin-walled Steel Enclosed Lightweight Foamed Concrete: A Novel Approach to Fabricate Sandwich Composite. Australian Journal of Basic and Applied Sciences. 5(12): 1727-1733.

[28] Khan MI. 2002. Factor Affecting the Thermal Properties of Concrete and Applicability of Its Prediction Models. Building and Environment Journal. 37(6): 607-614.

[29] Othuman Mydin MA, Wang YC. 2011. Elevated-Temperature Thermal Properties of Lightweight Foamed Concrete. Journal of Construction \& Building Materials. 25(2): 705-716.

[30] Herki BA, Khatib JM, Negim EM. 2013. Lightweight Concrete Made from Waste Polystyrene and Fly Ash. World Applied Sciences Journal, 21 (9): 1356-1360 